\title{
THE CASE AGAINST GOVERNMENT LIFE INSURANCE
}

\author{
E. J. Oglesby*
}

Life insurance for the workingman and the members of his family, commonly known as Industrial insurance, originated, in its present form, in England in 1854, about a year after a report of a parliamentary committee called attention to the need of the population for a more adequate and a more secure method of life insurance than was at that time available in burial clubs and friendly societies. ${ }^{1}$ Its evolution can be traced in an unbroken record through these burial clubs and friendly societies back to the trade guilds of the fifteenth century. Through all these centuries we see the continual struggle of the workingman to provide for the uncertainties of the future and to relieve the immediate and destructive pressure of poverty. It was as true then as it is now that under the constitution of society much of human poverty is unavoidable, but it is equally true that a large amount of misery is preventable by the cultivation of habits of saving and insurance.

Unfortunately, these early societies were formed almost exclusively by workingmen totally ignorant of the extent to which mortality increases with growing age, with the result that the benefits they attempted to provide were generally in excess of the amount that the contributions would secure. The inevitable termination of such plans by way of exhaustion of funds usually followed within a single generation. It was this situation which led to the inauguration of Industrial insurance by private life insurance companies. The phenomenal growth of the business was due largely to the elimination of uncertainty as to the financial stability of the organization undertaking to pay the benefits upon death. This venture represented the first attempt to incorporate proper principles in the life insurance of the industrial classes, and offered to the wage-earners the advantages of safe life insurance previously available only to individuals enjoying higher incomes.

A survey made in the United States in $1875^{2}$ indicated conditions similar to those existing in England prior to I854. Mutual aid societies had been formed by working-

* B.A., IgII, Emory and Henry; M.A., I9I4, University of Virginia. Professor of Engineering Mathematics, University of Virginia, since 193x. Head, Department of Mathematics, College of William and Mary, 1916-1919 (on leave in army I917-18); Chairman, Department of Mathematics, Washington Square College of New York University, 1919-1931.

${ }^{2}$ Report from The Select Committee on Assurance Associations (1853).

${ }^{2}$ Dryden, Life Insurance and Other Subjects (1909). 
men on unsound plans under which the benefits provided were out of proportion to the dues collected. It was not possible for workingmen to secure small amounts of insurance from any of the established life insurance companies, and the companies themselves made little or no effort to solicit risks on the lives of wage-earners. There was, therefore, a real necessity for insurance designed for the special needs of the workingman, and, as happened in England, the result was the introduction of Industrial life insurance.

Immediate success attended the venture on the part of commercial companies, which today stand pledged under Industrial life insurance policies to the extent of over \$17,000,000,000.

The question as to whether the results achieved in the field of Industrial insurance could be improved by transferring the business to the United States Government requires for its answer an analysis of what is being done today by the great Industrial companies, with a consideration in the case of each particular feature as to what prospect of improvement there would be under federal administration. There are two headings under which improvements might be suggested. The first is better service to the policyholder, and the second, a reduction in the cost of insurance. In what follows it is assumed for the time being that we are considering a government monopoly of Industrial life insurance rather than the entry of the government into competition with established companies.

In the matter of service to the policyholder, we may consider, first, whether claims would be more fairly or generously handled by a government bureau than by the insurance companies, and, second, whether the writing of insurance by the government would secure a better distribution of the total premiums paid by the typical working-class family.

In the matter of cost, the question will largely center around whether the government could handle the business without the usual agency force, and thereby, perhaps, secure a reduction in expenses; or whether with an agency force constituted much as at present the government could, nevertheless, finds ways and means of reducing the cost.

\section{The Problem of Clatm Setriements}

There does not seem to be any serious reason for supposing, in the case of the very large Industrial companies, that policyholders are treated unfairly in the matter of securing settlement of just claims. These companies are all mutualized, so that stockholders' dividends do not have to be considered. Also, the annual surpluses used for policyholders' dividends are so large that, in the company's transactions with the policyholders, there is no reason why any policyholder should be deprived of what is fairly his due, merely in order that a microscopic addition be made to the dividends returnable to the other policyholders. As the very breath of life of an Industrial company is its reputation, particularly in the matter of claim settlements, 
it is only reasonable to suppose that ordinary business acumen would dictate a liberal attitude towards policyholders.

There is considerable evidence that this is the case. One of the largest companies found that they became involved in a law suit in about one out of every two hundred Ordinary death claims, as compared with one out of every thousand Industrial claims. While the smaller amounts of insurance under Industrial claims might be expected to cause fewer appeals to the courts, nevertheless the very low proportion shown is evidence of general absence of friction in such settlements.

Possibly government administration would be as good in this respect, but government departments normally set up rules and adhere to them quite rigidly, a practice which might result in the number of disputed claims rising substantially.

Apropos of claim settlement, it is a little surprising to notice that objection has been taken to what is known as the "Facility of Payment" clause which enables the insurance company to pay the claim to any close relative of the insured, or to any person who has incurred expense for the maintenance of the burial of the insured. In practice this clause may occasionally result in the wrong person receiving the money. Sometimes the companies have been unduly prompt in making payment and there have been a few cases of a claim being paid twice because the second claimant established a strong legal position. In general this clause results in extremely quick settlement of Industrial claims. Usually there is no doubt to whom payment should be made, and the Facility of Payment clause does enable the companies to settle claims immediately without waiting for the claimant to produce legal evidence of his right to the proceeds of the policy. A speedy settlement is generally of great importance to the beneficiaries, and the company's reputation for quick payment is a very valuable asset. The possibility that government administration would secure improved service in the settlement of claims is very remote.

\section{“Overinsurance" and the Lapse Rate}

It has, however, been clamied that the selling of insurance would be handled more efficiently by a government organization, which could avoid putting pressure on its agency force to secure a large volume of business. The agent is pictured as being hounded by the insurance companies to increase his premium collections. No doubt fairly persistent pressure is exerted on the agency force to secure new business, but there is at least equal pressure to avoid lapses and secure revivals of lapsed policies, as a prevented lapse or a revived policy means as much financially to the agent as the issue of a similar new policy. Sometimes the burden of weekly premiums may seem to justify a charge of overinsurance. Prior to the depression, many families made use of steadily growing incomes to acquire from time to time additional policies. With the sharp reduction in almost all incomes, it naturally happened that the weekly premiums in many families were much bigger relatively than when the insurance was taken out. This has caused a lot of unjustifiable crit- 
icism to be directed against the insurance companies. It was precisely the families whose steady accumulation of Industrial policies caused the charge of overloading who had reason to be thankful for that "overloading" when the depression came, as they were able to secure from the insurance companies financial help in time of need by cashing in policies to a greater extent than was possible to those with less insurance.

At the end of 1933, the total Industrial insurance in force was 94 per cent of its highest record (in I93 I). Had there been a large proportion of true overloading, it would have been impossible for the workers' families, with incomes so greatly depleted, to have maintained almost the full volume of insurance placed in the years of ample incomes.

Whatever amount of business is transacted by the individual agent, his income must be maintained at about the present average, allowing, of course, for variations with changing economic conditions, if the quality of the personnel is to be maintained. If a large increase were made in the earnings of the agent, a still higher type of agent could be secured, but the cost to the policyholders would be unnecessarily increased. The current average earnings are sufficiently high to attract a sataisfactory type of agent, and neither a change to more highly paid persons with the increased cost, nor to a lower paid personnel with decidedly poorer service would be likely to prove of real value to the policyholders.

Assuming, then, that approximately the present average income to the agent is to be maintained, if the so-called pressure were to be released by establishing, as would be necessary, a very much higher scale of remuneration for a given volume of business, while some business written today that should not be written might be avoided, the actual amount taken from the pockets of the policyholders for direct expenses would be greatly increased in proportion to the amount of insurance carried.

The question as to how much business is written that should not be written must, of course, remain a matter of opinion. Some evidence, however, does exist to show that the volume cannot be very great. At the outset the lapse rate among Industrial policies is quite high, but it must be remembered that these policies are issued to people with irregular employment, and Ordinary insurance issued to those who have all-year-round jobs. So long as the working classes are subject, even in the best of times, to weeks or months without work, so long will there be a heavy lapsing of insurance in the early years of issue when the policyholder feels that the amount he has invested is not very substantial. When we get past the first year or two, however, and the policyholder does feel that he has a real interest in the maintenance of his insurance, the lapse rate becomes surprisingly low. The following figures have been supplied me by one of the principal insurance companies regarding the lapsing of Industrial policies after the second calendar year from issue, which means, on the average, after the policies have been in force for $I 8$ months. 


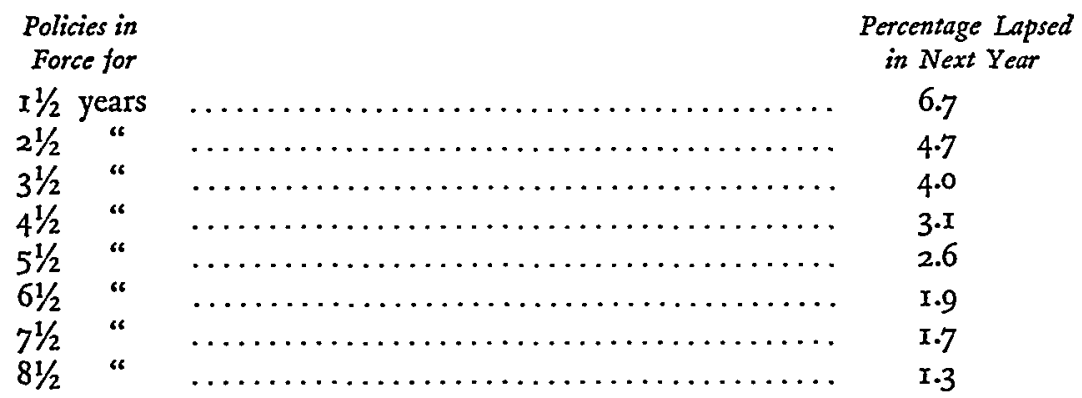

Lapses in the above table include policies surrendered for paid-up insurance. Except for the first two, the lapse rates were actually lower than in the same company's Ordinary business for the years indicated.

If it were true, as is sometimes claimed, that a vast mass of improper insurance is placed in the families of the workers, it is difficult to believe it possible that such phenomenally low lapse rates could be secured. These surprisingly low figures are emphatic evidence that the families are generally able to carry the insurance policies which have been placed on their lives by the agency force. At this point, it may be mentioned that the lapse rates given above, which were for the year 1928, were in every instance reduced for the year I929, but, with the coming of the depression, rose sharply, as those who normally would pay the premiums lost their jobs and were without the necessary funds. During the depression the stream of money turned in the opposite direction, and the large Industrial companies paid out many hundreds of millions of dollars in cash surrender values to the policyholders who had fallen upon evil days financially. Incidentally, as is well known, hundreds of thousands of the surrender values paid in cash were paid to policyholders whose contracts did not enable them to demand cash at all.

\section{Unsuitable Policies and Infantile Endowments}

As a good deal of stress has been placed on the question of improper writing of insurance, it may be pursued a little further. Perhaps the principal charge in this respect consists in a claim that endowments are issued freely on the lives of children to the exclusion of insurance on the life of the breadwinner. The necessity that exists for mass handling of the Industrial insurance records in order to keep the expense within reasonable limits, precludes such a scheduling as would bring together all the policies within a particular family. Thus, an investigation to determine whether or not the insurance premiums were wisely distributed cannot be readily made. Endowment policies, as the Japanese government's experience indicates, are with many people much more readily written than life contracts, and there can be no doubt that, human nature being what it is, some agents follow the line of least resistance and write the insurance where it is most easily secured rather than where it would be of most use to the family. On the other hand, it is doubtful if there are many families in which the amount of premium devoted towards endowments on the 
children is any real cause for the non-insurance or under-insurance of the breadwinner.

Evidence that the writing of infantile endowments rarely results in a reduction in the amount of insurance carried by the parents, and particularly by the breadwinner, may be found in the experience of one of the very large Industrial companies, which commenced writing infantile endowments in Igr4. As infantile endowments were not written in Igr3, had the writing of these affected seriously the placing of insurance on the breadwinner, we should have expected a fall in the number of policies issued to adults in I9I4 as compared with 1913. Actually the life policies issued to adults rose from $1,156,000$ to $I, I 87,000$, and the endowment forms issued to adults rose from 190,000 to 232,000 , so that the total adult policies increased from $I, 346,000$ to $I, 4 I 9,000$, an increase of over 5 per cent, notwithstanding that over 390,000 infantile endowments were issued in $\mathrm{IgI}_{4}$ and the total infantile issues were more than 150,000 policies greater than the infantile issues of the previous year. This suggests very strongly, indeed, that endowments to children for the most part represent money spent, perhaps as a luxury, but in lieu of some other luxury and not as the alternative to supplying the family's pressing needs in the matter of life insurance or other necessities.

Admitting that there may be a residuum of cases where too much is spent on children's endowments, which under better selling would have been used for insurance on the parents, and particularly on the breadwinner, one is at a loss to see how agents working for the government, remunerated in the same way as they are by the commercial companies, would handle matters any better. If in this respect better service were to be given to the policyholders, it could only be secured by changing the system of remuneration of the agency force or dispensing with agents altogether. These two possible alternatives may now be given some consideration.

\section{The Agent's Remuneration}

The insurance companies have found that the only practical way of remunerating the agency force is by way of commissions, and it follows that the agent's income depends on the amount of business that he writes. In the few instances where a different plan has been tried the results have been unsatisfactory. There seems to be every reason to believe that the payment of a salary to the agent, irrespective of the amount of business that he wrote, would produce much less business in proportion to remuneration received. This in turn means that the cost to the policyholders would be quite heavy, and the loss to the policyholders would certainly be more than now results from the writing of misplaced policies through the agent's response to the pressure upon him for writing business in order to secure the corresponding commissions.

In the absence of any evidence favoring a salaried agency force, and in view of the strong probability that human nature would follow its normal course, it would 
be exceedingly unwise to attempt to organize an agency force to write and service Industrial policies on other than a commission basis. If, therefore, under government administration an agency force is to be maintained, as a practical matter it would have to be paid as is now done by the companies, without any hope of improvement in the service rendered to policyholders. Indeed, if, as has happened so often under government administration, the supervision were more lax than it is under the company administration, the policyholders would be less well protected than they are under the present system.

\section{Government Insurance Systems Dispensing with the Agent}

The remaining alternative to be investigated, then, is that under which the government would handle the business without an agency force at all, or at least without an agency force at all comparable to that of the companies.

The possibility of the government supplying insurance on more favorable terms than the companies is by no means a new idea. The matter has, indeed, been tried quite a number of times, Where the usual agency system is not to be set up, the post office has been selected as the department to handle the insurance. It will be worth while, therefore to consider what has been done by the postal departments of the various governments that have tried the plan as affording, perhaps, some indication of what might be feasible in the United States.

\section{The British Post Office Assurance Plan}

The first effort of a government to handle life insurance as we know it today was that of the British Post Office Life Assurance scheme inaugurated in I864. This plan was intended to provide life insurance for the masses through the post offices situated all over the British Isles, and much was expected in view of the fact that the premiums charged were quite low. Substantial results, however, did not appear, and after $6_{3}$ years of operation the amount of insurance in force was just over a half million pounds sterling, while about two thousand times as much Industrial insurance was in force in the insurance companies. The Select Committee on Estimates in its report published July 28 , I928 stated: "Your Committee consider that it results in a mere distraction of Post Office energies which might be better employed, and, taking into consideration the immense strength of commercial insurance companies, the necessary restriction of investment of Post Office insurance funds to British Government securities, and the extreme difficulty of competing seriously for new business, they recommend that the Post Office Life Assurance business should be discontinued." The recommendation of this committee was adopted, and the writing of new insurance was discontinued at the end of 1928 . The first experiment in government insurance illustrates very' clearly the fact that insurance is sold rather than bought, and that, desirable as it is, it will not be procured today but rather left to the tomorrow that never comes, unless an active agency force presents the matter and 
importunes the individual to provide such funds as he may deem necessary to have available upon his death.

\section{The Japanese Government Monopoly of Industrial Insurance}

Very much more successful has been the effort of the Japanese government to write Industrial insurance through its post offices. ${ }^{3}$ In Japan Industrial insurance is a government monopoly and quite a substantial volume of business has been secured. The plan appears to require the applicants to call at one of the 9,000 post offices throughout the country to secure the insurance, and premiums-which are not weekly, but monthly-apparently are usually paid in the same way, although there is a reference to "collectors," which may or may not mean letter-carriers. As probably the poorer classes in Japan do not have a large amount of mail, it is unlikely that the collectors are also mailmen.

Some of the features of the Japanese experience are worthy of consideration. In the first place the lapse rate is quite high and, as in the case of the American companies, lapses increased with the depression, rising to a maximum in the fiscal year I93I-I932, and falling off somewhat in the year 1932-1933.

One outstanding feature of the Japanese experience is the sale of endowments, to a much greater extent than in the case of the American Industrial life insurance companies. In the case of these companies, the major part of Industrial insurance is on the whole life plan, whereas the return of the Japanese Government for the fiscal year 1932-1933 shows that over three-quarters of the policies and of the amounts of insurance in force are on the endowment plan, while the premium income from the endowment business is nearly five times that from whole life contracts. As the Japanese Government at the time of this statement had been writing infantile business for only two years, and as the infantile business consists solely of 15 -year and 20-year endowments, it is likely that as the proportion of infantile business grows, endowments will reach well over 80 per cent of the total business.

It is curious to note that while the endowments on infantile lives have been most severely condemned as a waste of money which should be spent for buying insurance on the parents, the Japanese department has not felt it feasible to offer whole life insurance at all on infants, but is issuing only 15 -year and 20-year endowments, more than go per cent of the applicants selecting the shorter term. It may be noted that, leaving out the infantile business, more than three-quarters of the adult policies now being issued are endowments, and a full three-quarters of those in force also are endowments. In this case we may assume the applicants were free from pressure on the part of the agent to take out endowments, yet endowments were selected by a great majority. This suggests that perhaps the writing of endowment insurance is a matter of demand by the public rather than of pressure by the agent, and the degree of blame placed upon the agency force for the undue issue of endowments may be lessened in the minds of those who have too hastily assumed that the agent dominated

${ }^{3}$ Bureau of Post Office life Insurance, Annual Report 1932-33. 
the situation and generally sold that which suited his purpose. While on this point it may be worth while to quote the experience of the American company previously mentioned which prior to I9I4 did not issue infantile endowments except under a complicated form known as a limited payment life and endowment policy which, on account of its rather complex provisions, was not very freely issued. The infantile issues of this company for the year 1913 with only the complicated form of endowment, and for the year IgI4 was a regular 20-year endowment, are of interest.

Infantile Issues-Number of Policies

\begin{tabular}{|c|c|c|}
\hline \multirow{2}{*}{\multicolumn{3}{|c|}{1913}} \\
\hline & & 1914 \\
\hline Life ....... & $\ldots \ldots \ldots \ldots \ldots \ldots \ldots \ldots \quad 448,000$ & 310,000 \\
\hline Endowment & 96,000 & 392,000 \\
\hline Total & 544,000 & 702,000 \\
\hline
\end{tabular}

From the above table we may gather roughly that of the 448,000 taking life policies in 1913 , only $3^{10,000}$ wanted them, the other 138,000 taking them only because of the absence of any attractive endowment contract. At the same time, the increase in the number of policies issued, namely, 158,000 , may be taken as representing individuals who would not insure their children at all as long as only the life form was available, but were glad of the opportunity to do so when it could be coupled with an endowment. It is a curious prejudice which prevents parents from providing burial funds for their children by means of whole life policies, though these same parents take insurance as incidental to the provisions of an endowment benefit. The fact remains that the availability of an endowment policy results more frequently in burial funds being provided by insurance.

The truth is that the Japanese experiment supplies very little indication of what would be likely to happen in case the United States Government should undertake the writing of Industrial insurance. The Japanese have been so long subject to an exaction of implicit obedience to the government authorities that the results in the relatively highly individualistic United States might, and, as far as one can guess, would, be very different. It is extremely probable that the British experience would be reproduced here, with the result that an invitation from the federal government to the workers of the United States to buy insurance at the post offices would almost certainly meet with a small response. If this were the only insurance available, we should find a vast increase in the number of families unable to pay funeral expenses and burdening themselves to a greater extent by borrowing for this purpose than they ever would have by the payment of Industrial premiums.

\section{Savings Bank Insurance in Massachusetts}

A further indication that this is the case may be had from the experience of the Massachusetts savings banks, where an effort has been under way for many years to provide low-cost insurance. The plan was authorized by the Massachusetts legis- 
lature in 1907. A large part of the expenses was provided initially by the state, and even to this day the state still pays part of the expenses but apparently plans to terminate such payments with the current year. It should be noted, however, that the savings bank insurance was not originally written wholly without agents. Several enthusiastic employers in the early stages hired agents at their own expense to go through the ranks of their employees and write insurance. Even at the present time apparently there are disguised agents, known as "Instructors," writing this insurance, which not being charged with the ordinary agency expenses, does constitute an economical method of providing death benefits. However, by October, 1933, only about 2 per cent of the total amount of insurance in force on the lives of Massachusetts citizens was carried in the savings banks. Apparently only a small part of this insurance is carried on the lives of workingmen for whom it was intended, as the average policy in force amounts to over $\$ 900$, though the maximum permitted in any one bank and, therefore, in any single policy is only $\$ r, 000$. This may be compared with the average Industrial policy of a little more than \$200. Part of the explanation may be found in the fact that government officials who have been brought into contact with the system frequently have availed themselves of its benefits, and by taking $\$ \mathrm{x}, 000$ in as many of the 20 savings banks writing the insurance as may be necessary, substantial amounts of insurance have been secured. Part of the cost of this insurance has been paid in the past by a state subsidy.

A special Commission for Investigation and Study of the Banking Structure of Massachusetts, in its report of January, I934, said:

"When savings banks were authorized to form a department of life insurance, the law provided that this department should be a distinct entity, but did not provide any effective means for the segregation of the expenses of this department from the general expenses of the savings bank itself. The result has been that some life insurance departments connected with savings banks have been charged nothing for rent, and, in some instances, little or nothing for clerical hire or management. It is believed that the interest of the public requires that the expenses of the life insurance departments in our various savings banks should be uniformly maintained and segregated from the general expenses of the savings bank itself so that the cost of such insurance may be fairly computed and that the rights of depositors and policyholders may be mutually protected."

The insurance in this case, while a small fraction of the total on the lives of Massachusetts residents, is relatively higher than in the British experiment, due in part to agency work, and in part to the realization by some government officials that insurance was available with part of the cost borne by the state.

\section{The Wisconsin State Fund}

Wisconsin is another state that has attacked the problem of the cost of life insurance, and the Wisconsin State Fund commenced issuing policies in 1913 in amounts from $\$ 500$ up to about $\$ 7,000$, with premiums payable annually, semi-annually or quarterly. This was, therefore, not an experiment in Industrial, but in Ordinary, 
insurance, and its only value in connection with the present problem is the indication of how unresponsive even the better educated portion of the community, which requires Ordinary insurance, is to a simple appeal to transact business inexpensively with the Government. At the end of I9I8, after about 6 years of operation, there were $46 \mathrm{I}$ policies in force for a total of $\$ 479,000$ of insurance, which caused Governor Phillipp to say to the Wisconsin legislature in January, I9I9: "The Insurance Department has kept up a continuous campaign for business through circularizing available lists. State banks and local officials do not send in business. . . . This Fund is based upon the theory that desirable life insurance risks voluntarily seek insurance. That theory is unsound-they do not do so. If this enterprise is to prosper and grow, as it must to have a normal experience, it must have an organization for soliciting business. If the expense of such an organization is incurred the Fund can offer no inducement not offered by privately managed life insurance companies and fraternal societies. ... I recommend that you repeal the statute under which this form of life insurance is being carried and direct the Insurance Commissioner to reinsure the present policyholders in a reliable company."

The Governor's recommendation was not followed, and at the end of I933, after about 2I years of operation, the insurance in force was something under $\$ \mathrm{x}, 500,000$, or less than one-thousandth part of the total in force on Wisconsin residents in insurance companies.

\section{The Practicability of a Government Agency System}

The above résumé of the results of government operation dispensing with the agent indicates that in the United States a mere appeal to the buyers of Industrial insurance to purchase from the government would be quite ineffective, and it may very reasonably be concluded that whether operated as a monopoly by the Federal Government or continued to be handled by the existing commercial companies, Industrial insurance to be provided at all in sufficient measure must be provided by a system of agents soliciting for new business.

\section{The New Zealand Experience}

The only government effort at life insurance worthy of consideration in this connection is that of New Zealand. New Zealand, with a large Scottish element in its population, was far too canny to attempt to write life insurance without a regular agency force. The Government Insurance office in New Zealand has been about as successful as an ordinary insurance company might have been. Its expense rate is higher than those of the best Australian companies (there are no commercial New Zealand life insurance companies of any consequence), and lower than the expense rate of the worst managed of these companies. The department has functioned quite satisfactorily, and just about as well as if it had been an independent mutual life insurance company. At the same time it has apparently functioned no better than a good mutual company. 
In passing it should be noted that the Commissioner in charge of the New Zealand Government Insurance Office is free from political interference in making appointments and conducting the business, a matter which will be referred to later on.

\section{The Letter-Carrier as Agent}

It might be suggested that instead of employing separate agents, the letter-carriers could, incident to delivering letters, write insurance and collect premiums. Obviously letter-carriers could be trained to handle this business also more or less efficiently, although it is probable that the present personnel could not be trained to handle the more complex business of Industrial insurance, except for the relatively recent entrants into the service. At first sight there is something intriguing in the idea. Instead of the mail-carrier walking around once to deliver letters and the second time to collect premiums, one round trip would do for both, but practical experience indicates very strongly, indeed, that an effort to train a force to handle these two entirely different sets of transactions would result in neither business being properly handled. The greatly increased force of mail-carriers which would become necessary would in course of time tend to divide into those who specialized in handling the life insurance and those who contented themselves almost wholly with delivering mail. As a result, we would almost certainly, before long decide as a matter of efficiency that the two businesses must be handled separately, and that the life insurance must be handled solely by trained life insurance men, whose time should not be taken up by the delivery of letters.

If it be conceded that as a practical matter the agency force must remain, no matter what organization carries the Industrial life insurance of the community, the above discussion has, perhaps, demonstrated the fact that no improved service to policyholders could be looked for under government administration, although it would be quite possible for the service to deteriorate.

\section{Are Industrual Insurance Costs Excessive?}

There remains the question of cost, which is one of the main objects of criticism of those who feel that Industrial insurance is in need of reform. It is very necessary in considering the question of cost to bear in mind that cost is entirely relative. If in order to provide adequate burial funds the present rate of expense is necessary, and such funds cannot be provided by any other device at less cost to those who need the funds, it is absurd to contend that Industrial insurance is secured at excessive cost. If, however, it could be shown that extravagant wages and salaries are paid in the Industrial field, or that through unskillful organization a great part of the expenditures were wasted, criticism would justly lie against the companies, but until it can be shown that the companies are spending unnecessary sums in order to provide the death benefits required, no criticism on the basis of actual cost is valid. 


\section{Computing the Cost of Industrial Insurance}

A great deal of sheer nonsense has been written and spoken about the cost of Industrial insurance. It is not at all uncommon to find wild statements that Industrial insurance costs twice as much as Ordinary, and sometimes the statements go a good deal further than this, notwithstanding the fact that even a most cursory inspection of the annual statement of any of the large Industrial companies will show how totally without foundation such statements are. Indeed, some commentators have gone beyond the double ratio, and three times, four times, six times, and even eight times the cost of Ordinary insurance has been by some device or other figured as the corresponding cost of Industrial insurance.

An apparently reasonable but in reality absurd device which has been used in some comparisons is to take the premiums paid for a number of years, respectively under Ordinary and Industrial policies, and ignoring the interest accumulation, to deduct from the premiums paid for a five-year or ten-year period the surrender value at the end of such period, the resulting figure being called the "cost of insurance." It is obvious that the true cost should include interest on the premiums paid, and that the real cost of insurance would be better shown by term insurance premiums less whatever dividends are allowed thereon. An insurance policy under which, in order to carry the contract for the whole of life, substantially more than the current cost is charged in the early years, makes it possible to return the additional amount with interest as part of the surrender value, so that it is not surprising to find that the so-called net cost over to years for Ordinary.insurance may under some forms of policies appear to be less than one dollar per thousand per annum, whereas at the very best it must range between $\$ 5$ and $\$ 10$, even at the younger entry ages, with substantially higher figures for the older ages.

Perhaps no more conclusive demonstration of the fatuity of this method of comparison is necessary than the following figures, showing for age 20 at entry the "cost" over a twenty-year period of Ordinary and Industrial insurance in a large company.

\begin{tabular}{|c|c|c|}
\hline Amount of Insurance $\$ 1,000$ & Industrial & Ordinary \\
\hline Premium per annum ... & $\$ 24.96$ & $\$ 18.00$ \\
\hline Premiums for 20 years $\ldots \ldots \ldots \ldots \ldots \ldots \ldots \ldots \ldots \ldots \ldots$ & 5or.r2* & $295 \cdot 47^{* * *}$ \\
\hline Cash Value end of 20 years................... & $452.87^{* * *}$ & $x 87.00$ \\
\hline "Net Cost" & $\$ 48.25$ & \$108.47 \\
\hline
\end{tabular}

The indicated difference is emphasized by the fact that under the Industrial policy dividend returns take the form of additions to the insurance, so that during the twenty-year period the death benefit would range from the initial $\$ \mathrm{I}, 000$ up to $\$ \mathrm{r}, 500$, averaging a trifle under $\$ 1,200$.

If these figures told the whole story, in this instance at least, Industrial insurance 
would be shown to be less costly than Ordinary. Actually, of course, the Industrial contract involves the higher outlay, the improper method of comparison being responsible for the paradox.

Comparisons of this kind, moreover, deal only with what happens if the policyholder does not die but surrenders his policy. To decide that the net cost of insurance can be determined by considering the cost to those alone who do not die during the period for which costs are considered is no more correct than to affect to settle the problem by a comparison of the net profits to the estates of only those who die during the same period. If we consider only the profits enjoyed by the beneficiaries of the policyholders who die during so many years after issue, we shall naturally, owing to the higher death rate among Industrial policyholders, be able apparently to show, with at least as great justification as exists in the usual comparison, that Industrial insurance is a very much more profitable venture than Ordinary insurance. For instance, the following figures show at entry age 40, the amount that would be paid, using the actual mortality rates of one of the large companies in its respective Industrial and Ordinary departments, during a five-year period (assuming for the sake of convenience that no policies lapse during that period). The basis of comparison is taken as a million dollars of original insurance in each case.

\begin{tabular}{|c|c|}
\hline $\begin{array}{l}\text { Death claims for five years. } \ldots \ldots \ldots \ldots \ldots, \ldots, \ldots, \ldots \\
\text { Dividends of all kinds paid } \ldots \ldots \ldots \ldots \ldots \ldots \ldots \ldots\end{array}$ & $\begin{array}{r}\text { Industrial } \\
\$ 43,810 \\
768\end{array}$ \\
\hline 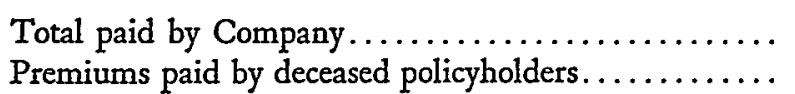 & $\begin{array}{r}\$ 44,578 \\
5,365\end{array}$ \\
\hline Profit to policyholders or their beneficiaries. & $\$ 39,213$ \\
\hline
\end{tabular}

For what it is worth, the above table indicates that, per thousand dollars of insurance entered on, considering only those who die, the profits during the first five years are about twice as much under Industrial as under Ordinary insurance, notwithstanding that higher premiums are charged in the Industrial, and this condition would persist to some extent even though the period covered was extended to ten or twenty years. The really important fact developed by the above table is that in the case of Industrial insurance much more has to be paid out in the early years for claims than under Ordinary insurance. To call this extra distribution to the policyholders extra cost to the policyholders seems a little absurd, and to criticize the Industrial companies because this larger distribution to the families of the decedents leaves relatively less to return to living policyholders is sheerest nonsense. No one complains that the premium for life insurance on a man aged $5^{\circ}$ is higher than for a man aged 20, because everyone recognizes that insurance effected on lives aged 50 will mature sooner for death claims and with fewer premiums paid thereon than in the case of policies taken out at age 20. As fewer premiums will be paid with less 
time to accumulate interest, necessarily larger premiums must be charged. Exactly the same situation arises in the case of Industrial insurance, a very large part of the criticized extra cost being merely the larger proportionate distribution of premiums by way of claims among the policyholders.

\section{The Possibility of Governmental Economies}

The other item of cost is the expense of conducting the business. No one claims that government administration will prevent an insured policyholder from dying, so that the only possible advantage in the matter of cost under government administration would be in the savings in expenses. This one possible source of saving, or possible source of loss, deserves careful consideration.

In the preceding arguments we have demonstrated the impracticability of any substantial change in the organization of the agency force were the business conducted by the federal government. No doubt, it will be readily admitted that the government could not greatly reduce the remuneration of the agents without impairing the service. Moreover, it is very doubtful if the community as a whole would desire to see these wages reduced, for though the Industrial field work offers a reasonably satisfactory opportunity to energetic and enterprising individuals to make a satisfactory income, it does not produce an average wage that could be considered unduly high. For the most part it ranges from rather more than \$20 a week to, perhaps, in some cases $\$ 60$ or $\$ 70$ a week. The average is stated to be not far from $\$ 40$ a week. Included in this are the earnings made by these agents in writing Ordinary business as well as Industrial. Considering the fact that the Industrial agent has to give up as a rule one or two nights a week at least to make calls on his clientele, the rate of wages is not unreasonably high and no substantial reduction seems desirable or practicable.

Perhaps enough has been said to demonstrate the practical impossibility of conducting Industrial life insurance without an agency force, but it may be well to consider how the various dealings between policyholder and company would have to be carried on if the agency force were abolished.

First of all there would' have to be a very great addition to the clerical force of the district offices, or, under federal administration, the post offices, as the recording of premium payments now made by the agents as they go their daily rounds would have to be done in the district offices, and while the increased clerical force for this purpose would not be nearly equal to the number of agents, it would represent a very substantial part thereof.

Next would come the matter of settling claims. The work done by the agent in supplying the necessary forms and in assisting their completion would in part, again, be transferred to the district offices, and a further addition to the staff of the district office would be necessary to deal with claimants. As the office staff could not be as familiar with the individual situation as the agent visiting the homes from week to week would be, more difficulty and friction would naturally arise in the 
changed method of disposing of claims. Also, there would be a great number of cases where notice of the claim was sent through the mail, which would mean an increase in the amount of correspondence on account of claims, with the consequent necessary increase in the stenographic force in the district offices, and also in the home office.

Next we have the question of inquiries by policyholders as to various matters. These would be addressed either to the home office or to the district office. The status of a policy as to premium payments is determined from the premium receipt book, and as the vast majority of inquiries now are addressed to the collecting agent, the necessary information to enable the matter to be disposed of promptly with the minimum of labor is supplied, as the agent transmitting the inquiry is in a position to quote the date to which premiums have been paid, Moreover, a vast number of minor inquiries are disposed of by the agent personally. The immense increase in the difficulty of handling inquiries by correspondence as compared with a personal interview is well known to all those who have had to handle such matters. In practice the home office would receive a huge number of inquiries which would have to be transmitted by correspondence to the district office in order to locate the policies, and it would very often happen that the district office first selected might not be the one through which premiums were being paid, in which case further correspondence and delay would ensue in endeavoring to obtain the necessary data so as to furnish the required information. Alternatively, there would have to be kept in the home office, as well as in the district office, a complete record of all premium payments. It will be seen that the increase in staff required at the home office and district office to take care of the duties now performed by the agents would go far to offset the expenses saved by abolishing the agency force.

In the United States of America, however, there is one further factor that would not be present to nearly the same extent in either Oriental or European countries. This is the extraordinary mobility of the American populace. One of the large companies with approximately thirty millions of policies on its books found that, on the average, the number of weekly changes of address involving the transfer of the collection from one agent to another was 200,000. This means upwards of to million changes of address in a year, one policyholder out of three making an annual move. The collection agent generally knows in advance of the intended removal and learns of the new address, which is promptly supplied to the company and new collecting arrangements are put into effect.

In other words, for many of the operations the strategic point for disposing of the matter is the home of the insured, and the company's representative in the home handles the matter most economically. There is little reason to doubt that any direct saving in the company's expenditures would be more than offset by increased postage and traveling expenses on the part of the policyholders writing or journeying to the district offices. The fact of the matter is that the agency system is a highly economical 
way of writing the business and collecting these very small premium units instead of being, as is sometimes claimed, an extravagant device.

We may now consider the question of the home office payroll. This appears to represent in a large company something between 2 and 3 per cent of the premiums. If it could be abolished altogether, the saving would not be very important, and so far as the highly paid officers are concerned, I have been supplied with figures by one such company which indicate that if all the executive officers worked without any salary at all, the saving to the holder of a 5 cent weekly premium policy would not be as much as a single cent each year. There is obviously, therefore, in this direction, no large field for economy on the part of any government organization.

As a matter of fact, in view of the existing methods of organization and administration of government departments, a large increase in home office expenses would be expected. The spoils system would result in the employment of persons distinguished for political loyalty rather than for business efficiency, and changes in the political administration would be reflected in a discontinuous policy to the detriment of the holders of life insurance contracts. Unpleasant as this subject is, to ignore it altogether, and to assume that these conditions would not affect the filling of most of the clerical and official posts in the proposed organization, is to ignore the facts and assume a condition which cannot possibly exist, until political activities in the United States are vastly improved.

An important item of expense which might be eliminated if the government took control is the matter of taxes. Looking over the accounts of one of the large companies, I noticed that for 1933 the taxes paid in the Industrial department, exclusive of taxes on real estate, were 25 per cent greater than the total payroll of its home office clerical and official forces. This brings us to a new aspect of the Industrial insurance situation, the fact being that in addition to providing Industrial insurance, the life insurance companies, Industrial equally with Ordinary, maintain organizations for the collection of taxes, and not only pay heavy taxes to various governing bodies, but also carry extensive special accounts so that the proper amount of such taxes may be ascertained, and relieve the community of the expense to which it would otherwise be put of collecting the taxes directly. Of all the critics of Industrial insurance, so far as the writer knows, not a single one has suggested that the taxes assessed on Industrial business should be at a lower rate than those on Ordinary. While it is true that the federal government might operate without these taxes, it would merely mean that the community would be put to raising the taxes in some other and, perhaps, more expensive way, so that the gain would be entirely illusory, and the workers, who inevitably pay a full share of taxes however they may be levied, in the long run would not avoid a dollar of the taxes now levied on them through the Industrial insurance companies.

Furthermore it is extremely probable that the premiums collected under government operation of the business would in these United States be borrowed by the 
government as part of the federal obligations, in which case the interest return would range from between $x 1 / 2$ and 2 per cent less than that actually earned by the commercial companies. From the national point of view, this clearly would not be any loss, but to these particular policyholders of the working class there would be an important charge against their Industrial insurance that would represent, say, something between 5 and ro per cent, of their premiums. Some of this difference would doubtless come back indirectly, but the major part of it would probably represent a definite additional burden on the policyholders. .

\section{The Record of the Private Companies}

If the companies in the past had been negligent in the matter of giving their policyholders the benefits of new ideas and improving conditions, a hope for fairer treatment from the government might be justified. The record, however, is emphatically not one of negligence, and the best guarantee that the Industrial policyholders will be fairly treated in the future lies in the history of the past, which shows that many changes in favor of the policyholders have been made. The two largest companies both commenced as stock companies, and both have been mutualized to the very obvious advantage of the policyholders. Let us take the history of some of the concessions affecting older policyholders in one of these companies. A policy issued in 1885 at age $I 8$, at a premium of to cents a week, by its terms called for a death benefit of $\$ 216$, the contract being strictly non-participating, notwithstanding which the following series of changes in favor of the policyholder have been put into effect by this company:

The face amount of insurance has been raised to $\$ 220$, due to the fact that this latter amount was subsequently used by the company for this form of contract.

Dividends were paid in cash to the policyholders commencing at the end of fifteen years and thereafter at five-year intervals, with yearly dividends established from and after the mutualization of the company in 1915 . These dividends today provide that in the event of the death of the policyholder, the amount of insurance will be $1661 / 4$ per cent, not of the original amount but of the increased amount.

It has also been provided that when the policyholder reaches the policy anniversary prior to age 75, no further premiums will be required from him. This concession was made a year-to-year arrangement for a number of years, and applied to the policyholder reaching the required age each year. It has, however, subsequently been made part of the guarantee, so that the company now cannot change its attitude in this matter.

A disability benefit was provided so that in the event of the loss of two members (arms or legs) or the complete loss of the sight of both eyes, the insurance with additions would be made fully paid-up, to be payable upon later death, and exactly the same amount would also be paid immediately to the policyholder.

An accidental death benefit (prior to age 70 ) was added to the policy, the amount of such benefit being equal to the face amount of the insurance, not including the dividend additions. In the case of death while engaged in certain hazardous occupations, this benefit is of half the face amount. 
As a result of these concessions, if the policyholder had become disabled in the present year, and later on had died by accident, the total amount paid to him and his beneficiaries would have been $\$ 951.50$, or well over four times the amount of the original undertaking. One may wonder if under government administration any result approaching this would have materialized, or whether the growing margins which these mutual companies used for the benefit of the policyholders would not have been diverted to some political purpose.

These are not the only benefits included in today's policies and added to old policies by concession. Omitting many minor items I may mention the introduction of a grace of four weeks in payment of premiums, the allowance of cash surrender values and paid-up policies to those who were unable to maintain premium payments, while those who cease premium payments and fail to apply for cash or paid-up policies nevertheless continue to be covered for the full amount of insurance as long as their equity will carry the insurance.

While the examination made above does not indicate that there is no room for improvement in the conduct of Industrial insurance, it does suggest very strongly, indeed, that improvement is not at all likely to come via a federal government monopoly of the business. The records show that many improvements by way of concessions to policyholders have been made by the great Industrial companies, and as a final word it may be pointed out that with over 8r,000,000 policies in force today, it must be conceded that the field of operations has been covered with a degree of thoroughness that few other businesses can claim. The object of Industrial insurance is to provide that funds are available on the death of any member of a worker's family. The extent to which this desideratum has been secured is convincing testimony that, on the whole, the Industrial life insurance companies have done their jobs excellently. This fact, coupled with the continual concessions to policyholders, gives, perhaps, the strongest grounds for believing that destruction of the present organization and its replacement by a government bureau would represent little short of disaster to the working classes of the United States. 